\title{
Complement in nephritis
}

\author{
ROGER GABRIEL* \\ M.Sc., M.B., M.R.C.P., D.C.H. \\ Medical Unit, Westminster Hospital, London, S.W.1
}

\section{Introduction}

It has long been known that complement may be abnormal in patients with nephritis (Gunn, 1914). More recently, increasing interest has been paid to the role of complement in immune disease of the kidneys.

This paper reviews current information regarding complement and indicates its relevance to the clinical problem of nephritis.

\section{Evidence for complement involvement in glomerulonephritis \\ Clinical measurements}

In acute nephritis the serum level of complement is usually reduced, often to one-tenth of normal. This reduction is short lived and within 2-3 weeks the complement concentration returns to normal (Fig. 1).

In certain circumstances an autoantibody (immunoconglutin) to one of the complement components can be demonstrated in patient's serum after a nephritic episode has occurred. As the complement returns to normal with resolution of the nephritis, the titre of immunoconglutin rises for a period of some weeks (Fig. 2).

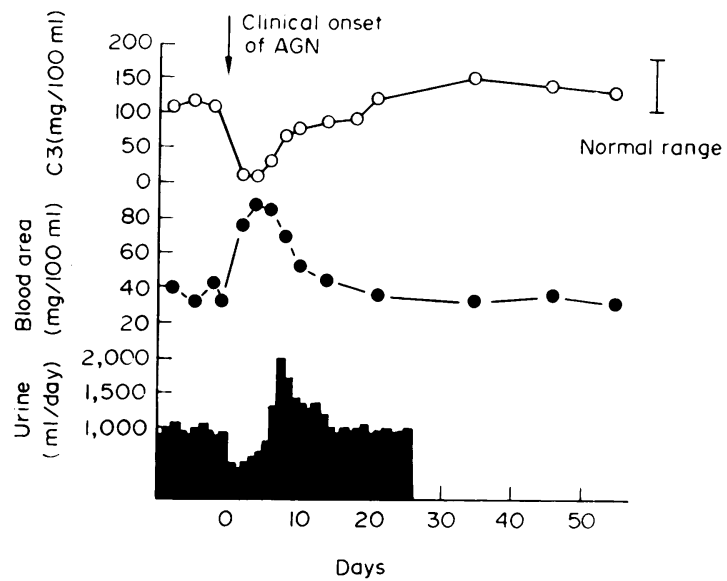

FIG. 1. Complement concentrations measured during an acute glomerulonephritis (AGN).

* Address for reprints: 7 Palgrave Road, London, W.12.

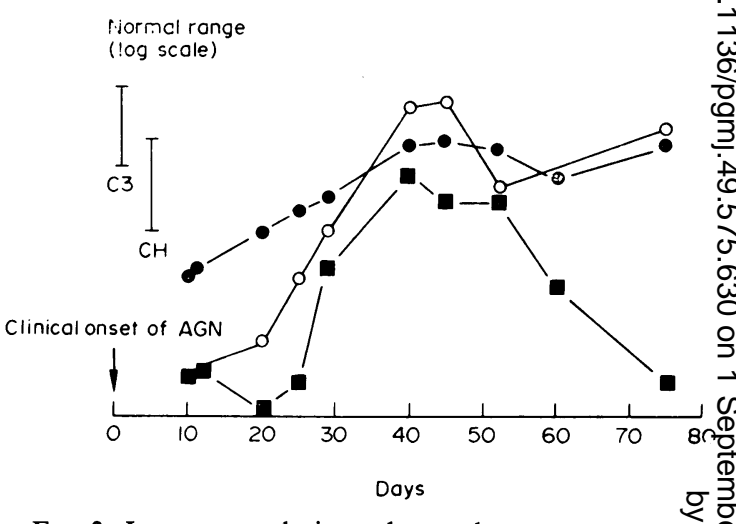

FIG. 2. Immunoconglutin and complement concentrations following an acute glomerulonephritis (AGN)응 (Redrawn from Ngu \& Soothill, Clinical and Expert 6 mental Immunology (1969) 5, 557, by permission of the

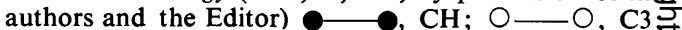
-——, immunoconglutin.

\section{Immunoelectrophoretic measurements}

Soothill (1967) has demonstrated an altered (C3a) $\stackrel{\mathbb{D}}{\perp}$ component of the third component of complement $\vec{F}$ in the serum of forty-six out of fifty-two patients with various forms of glomerulonephritis.

\section{Fluorescent studies}

Antisera to the third component (C3) are available, If such an antiserum is labelled with fluoresene, fluorescence occurs when exposed to ultraviolet. light. If unfixed fresh renal tissue from a patient withô active nephritis is taken and treated with such an antiserum, the antiserum reacts with $\mathrm{C} 3$ in the renalo tissue. When exposed to ultraviolet light, fluorescence indicating the site of the $\mathrm{C} 3$ is seen, predominantlyㅡㅡㄹ in the glomeruli. With full resolution of the nephritisn C3 is no longer demonstrable in the kidney.

\section{Evidence from experimental studies}

In the autoimmune nephritis of $\mathrm{NZB} \times \mathrm{NZW} \mathrm{F}_{1} \mathrm{O}$ hybrid mice, C3 has been demonstrated in theo glomeruli. The nephritis of these mice is associated with accumulation of antigen-antibody complexes in? the kidney (Lambert \& Dixon, 1968), and complement is bound with gamma globulin in the glomeruli 
(McGiven \& Hicks, 1967). For this autoimmune nephritis to progress, complement has to be continually utilized.

In the experimental nephrotoxic serum nephritis, serum complement falls both at the time of the autologous and the homologous phase (Earle, 1959). If the animal is de-complemented immediately prior to the induction of the nephritis the severity of the proteinuria and the nephritic lesion is much reduced (Hammer \& Dixon, 1963).

Thus, from clinical and immunological measurements there is strong evidence that complement is necessary for the genesis of an acute lesion, and probably for the maintenance of a chronic lesion.

\section{Nature of complement}

The activity ascribed to complement depends upon the operation of nine protein components (C1-C9) acting in sequence. Activation of the first component by an immune complex, such as an antibody bound to glomerular capillary walls, sets in motion a cascade, activating the other eight components, analogous to the blood coagulation system. A number of inhibitors are present to avoid adventitious activation.

\section{Sequence of complement activity}

Fig. 3 outlines the sequence of activity of the complement components. The activation of $\mathrm{Cl}$ is initiated by the binding of one of its subfractions (C1q) to altered sites on the immunoglobulin (antibody) $F c$ region produced by formation of a complex with antigen. Four important consequences follow the activation of complement in the glomeruli. As C3 is taken into the accelerating cascade, altered fragments (C3a) are released which chemotactically attract polymorphonuclear leucocytes. Secondly,

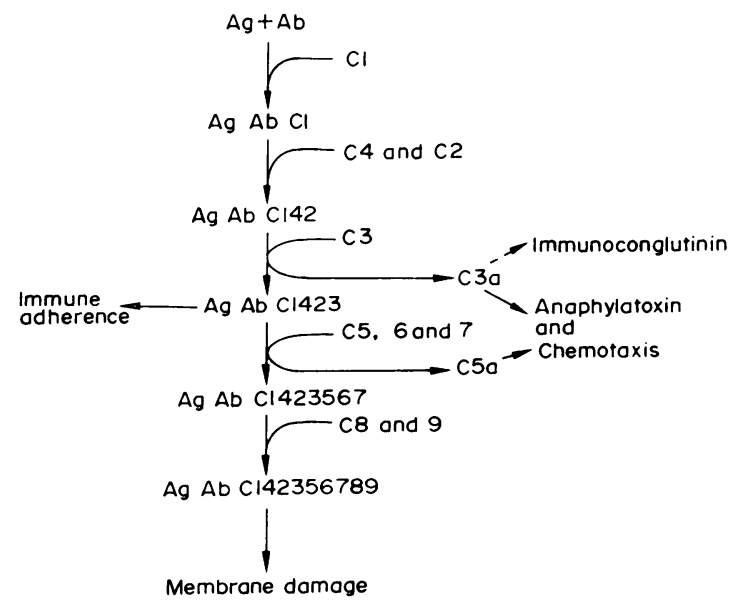

FIg. 3. The sequence of complement activation. Ag; antigen; $\mathrm{Ab}$; antibody.
C3a also has an anaphylatoxic effect, causing vasoactive amines to be released. The altered fragments of C5, C5a, also have these same properties as does C3a. The vasoactive amines-histamine, 5 hydroxy-tryptamine, bradykinin and slow releasing substance-enhance capillary permeability, increasing the inflammatory response. The involvement of $\mathrm{C} 3$ and the complement cascade has a third important effect-immune adherence. This is binding of $\mathrm{Ab} \mathrm{Ag} \mathrm{C1423} \mathrm{(Fig.} \mathrm{3)} \mathrm{to} \mathrm{the} \mathrm{glomerular} \mathrm{capillary}$ loop (or surface of a bacterium), hence localizing the site of the inflammatory response. The fourth effect of complement activation occurs when C8 and C9 are consumed and membrane damage occurs. In the case of the bacterium, multiple holes are punched in the membrane by phospholipase activity. Through these holes molecules can diffuse in and out and disruption of the cell contents occurs. Presumably similar damage occurs in glomeruli after complement activity.

\section{Measurement of complement and its components}

Total complement activity $(\mathrm{CH})$ is measured by its ability to lyse red cells; the haemoglobin released is in direct proportion to the complement activity of the test serum. The method used is usually that of Mayer (1961). Normal human sera possess about $45 \mathrm{CH}_{50}$ units/ml of haemolytic complement activityo

Of the individual components, only $\mathrm{C} 3, \mathrm{C} 4$ and $\mathrm{C} 5$ are present in sera in sufficient concentration to be measured by single radial diffusion technique. C3 has a normal concentration of about $90-170 \mathrm{mg} /$ $100 \mathrm{ml}$, and $\mathrm{C} 4$ about $10-30 \mathrm{mg} / 100 \mathrm{ml}$.

\section{Pathogenesis of glomerulonephritis}

There are two main types of antigen-antibody reaction considered to be involved in the pathogenesis of a nephritis. These are designated as Types II and III by Gell \& Coombes (1968). Both reactions are complement dependent. The Type II reaction is initiated when an antibody reacts with either an antigenic component of the glomerulus or with an antigen or hapten intimately associated with glomerular basement membrane. This is the Masugi experimental nephritis (Masugi, 1933). The clinical counter-part is probably Goodpasture's syndrome (Duncan et al., 1965).

Fluorescent studies of glomeruli from either the experimental model or from patients with Goodpasture's syndrome show linear deposition of anti-C3 conjugate lining the luminal side of the glomerular capillary loops (Fig. 4).

The Type III allergic response occurs when antigen in excess reacts in the blood stream with potentially precipitating antibody forming soluble circulating complexes, which are deposited in blood vessel walls, such as glomerular capillary loops, causing local 


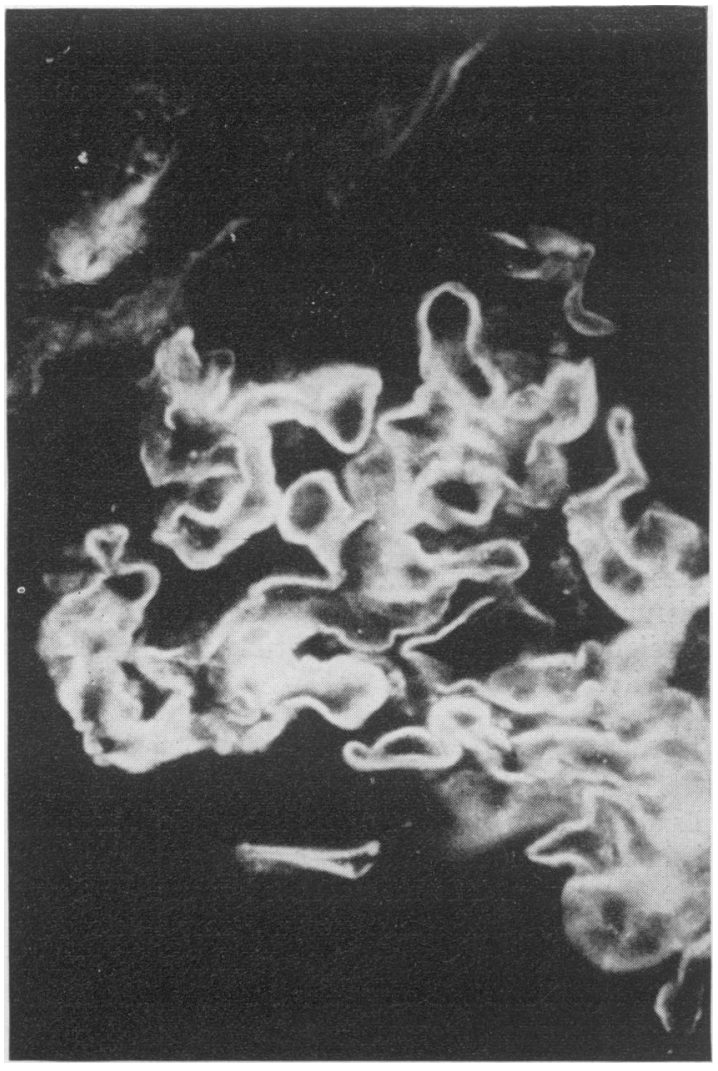

FIG. 4. Linear deposition of anti-C3 conjugate from a case of Goodpasture's syndrome (by courtesy of Dr D. Doniach).

inflammation. In the animal model this is 'serum sickness nephritis' (Dixon et al., 1958). From fluorescent studies of human renal tissue it appears that this soluble complex nephritis is responsible for the majority of human nephritides (Berger, Yaneva $\&$ Antoine, 1969). Fluorescent studies show multiple discrete deposits of anti-C3 conjugate lying within the capillary walls and mesangium of the glomerulus (Fig. 5).

\section{Complement measurements in clinical nephritis}

Measurement of haemolytic complement $(\mathrm{CH})$ or the third component (C3) randomly during the course of many nephritides will probably produce results in the normal range.

Alteration of the concentration of $\mathrm{CH}$ or $\mathrm{C} 3$ is interpreted usually as an indirect measure of the activity of the nephritis. However, a decline in renal function is not necessarily accompanied by variations in $\mathrm{CH}$ or $\mathrm{C} 3$ concentrations. Although evidence is lacking, it seems probable that most nephritides during some stage in their evolution will show abnor-

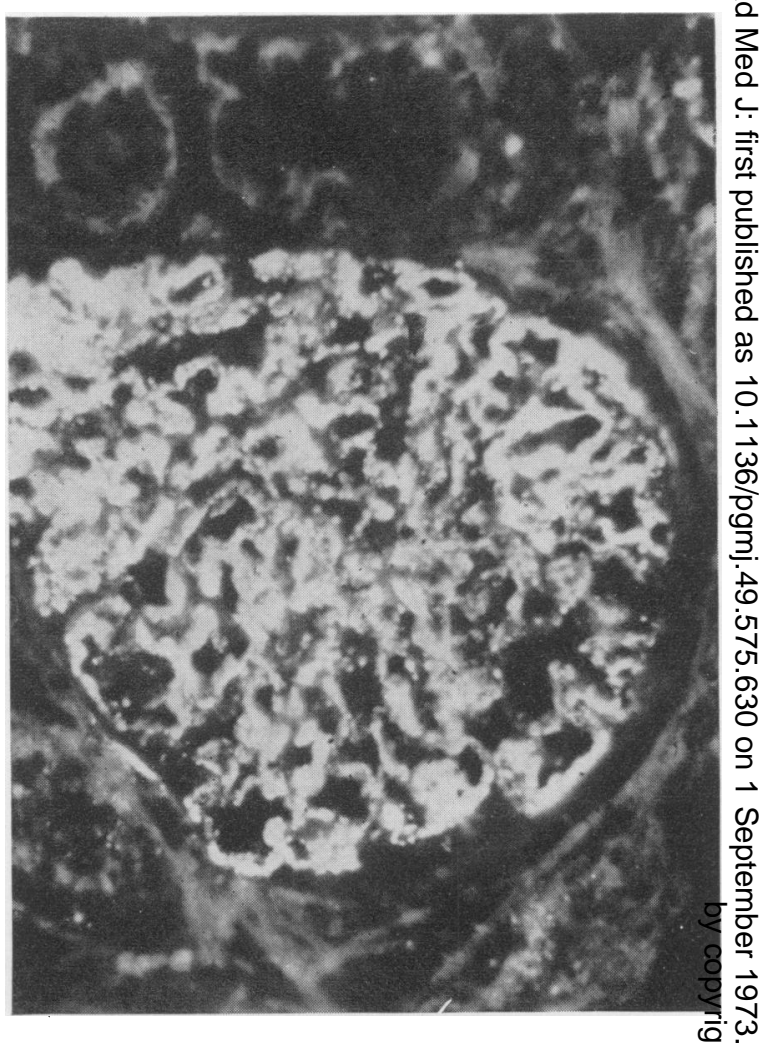

FIG. 5. Multiple discrete deposits of anti-C3 conjugate within a glomerulus from a case of membranoproliferative glomerulonephritis.

malities in the complement titres. Studies on complement in glomerulonephritis by many workers have shown that some nephritides are regularly associated with low $\mathrm{CH}$ and $\mathrm{C} 3$ titres, and some patients have increased concentrations of $\mathrm{CH}$ or $\mathrm{C} 3$, or both.

\section{Hypocomplementaemic nephritis}

There are four nephritides in which $\mathrm{CH}$ and $\mathrm{C} 3$ are lowered. These are:

(1) Acute post-streptococcal glomerulonephritis (Gottof et al., 1965).

(2) The acute focal nephritis of disseminated lupus

nephritis (Schur \& Sanderson, 1968).
(3) The nephritis accompanying subacute bacterial endocarditis (Gutman et al., 1972) or an infected $\mathcal{N}$ ventriculo-atrial shunt (Lam, McNeish \& Gibson, 1972).

(4) Membranoproliferative glomerulonephritis (Herdman et al., 1970).

In the first three examples complement concentrations are characteristically lowered at the acute phase of the illness and return to normal with resolution of the lesion (an idealized example is 
shown in Fig. 1). In membranoproliferative nephritis complement abnormalities are often prolonged and do not correlate with the clinical state or with any known biochemical parameter.

\section{Membranoproliferative glomerulonephritis}

Since 1965 it has become possible to group some nephritic patients on the basis of a characteristic morphological renal lesion (West et al., 1965). Histologically, the glomeruli are enlarged, the capillary loops are much thickened (Fig. 6) and later the tufts become lobulated (Fig. 7). With silver impregnation stains, the stain is taken up by the capillary wall on both the luminal and epithelial sides (Fig. 8). Fluorescent studies demonstrate granular deposition of $\mathrm{C} 3$ within the glomeruli (Fig. 5).

Membranoproliferative glomerulonephritis (MPGN) is more common in the female, has a protracted course but of shorter duration than that of membranous nephropathy, and is little if at all influenced by cytotoxic or steroid therapy (Cameron et al., 1970; Herdman et al., 1970). These authors state that MPGN presents in childhood or early adult life.

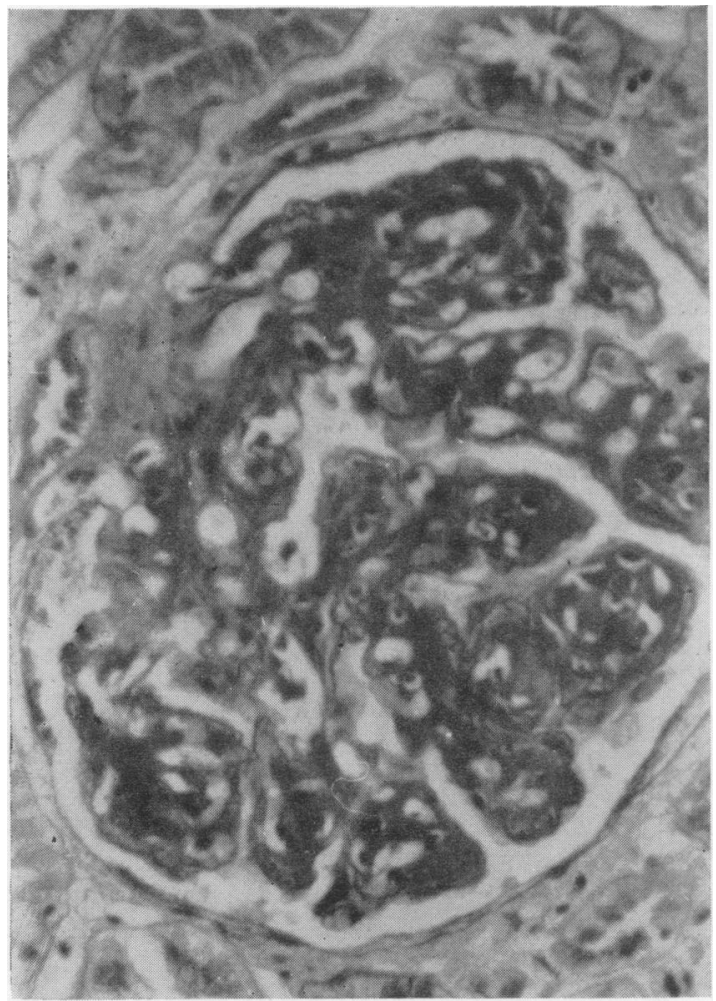

Fig. 6. A glomerulus from a case of membranoproliferative glomerulonephritis illustrating the thickened capillary loops (AB PAS $\times 208$ ).

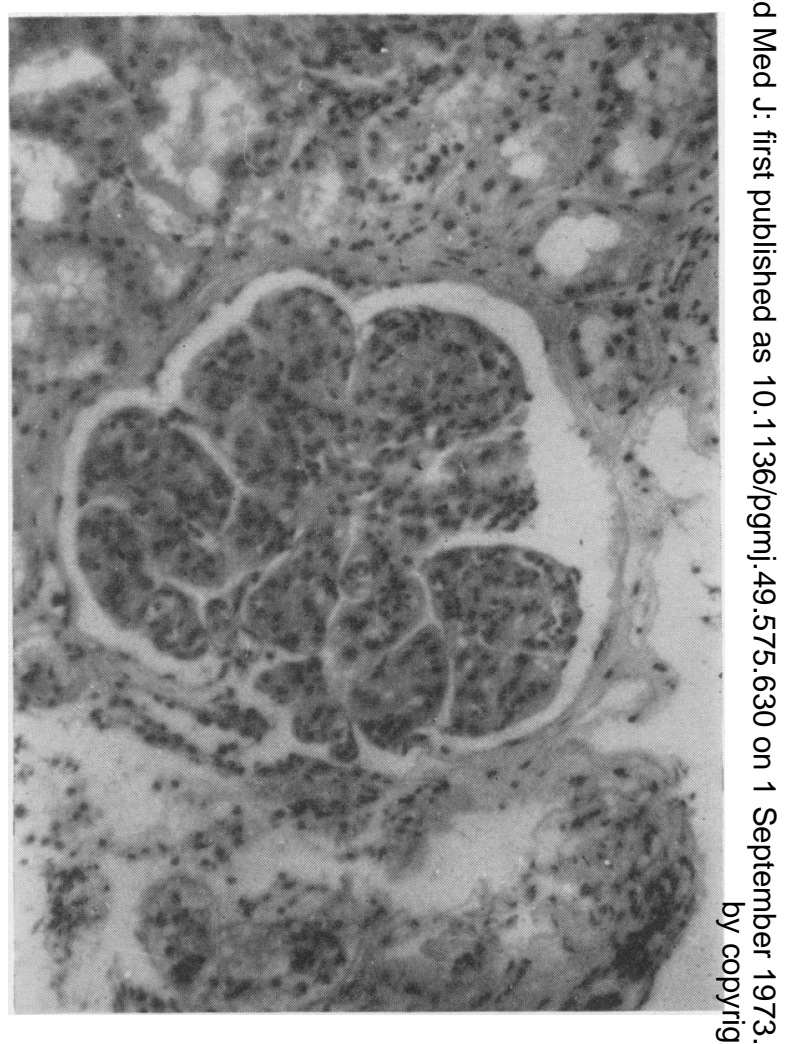

FIG. 7. A moderately advanced membranoproliferative glomerulonephritis showing lobulation of the tufts. The creatinine clearance was $25 \mathrm{ml} / \mathrm{min}(\mathrm{H} \& \mathrm{E}, \times 156)$.

Initially it was thought that C3 was invariably reduced in the patient with MPGN. West \& McAdams (1970) showed that serum C3 levels may return to the normal range during the illness, and Cameron et al. (1970) noted that the C3 concentration may never be low. Cameron et al. (1973), reviewing seventy-three patients with MPGN, found that the actuarial survival of the patients with normal C3 concentrations was similar to those with low $\mathrm{C} 3$ concentrations in their serum. All the patients of Herdman et al. (1970) had reduced serum haemolytic activity, and twenty-one out of twenty-four had reduced $\mathrm{C} 3$ concentrations at presentation.

Diminished synthesis (Alper \& Rosen, 1967), urinary loss (Lagrue, Brecy \& Hartmen, 1969) and increased consumption have been advanced to explain the hypocomplementaemia. However, it is generally considered that these mechanisms play little or no part in maintaining the reduced complement concentration.

Spitzer et al. (1969) have reported the presence of a so-called $\mathrm{C} 3$ nephritic factor $(\mathrm{C} 3 \mathrm{NeF})$ in the sera of patients with MPGN which can break down C3 when incubated with normal human serum. A low 


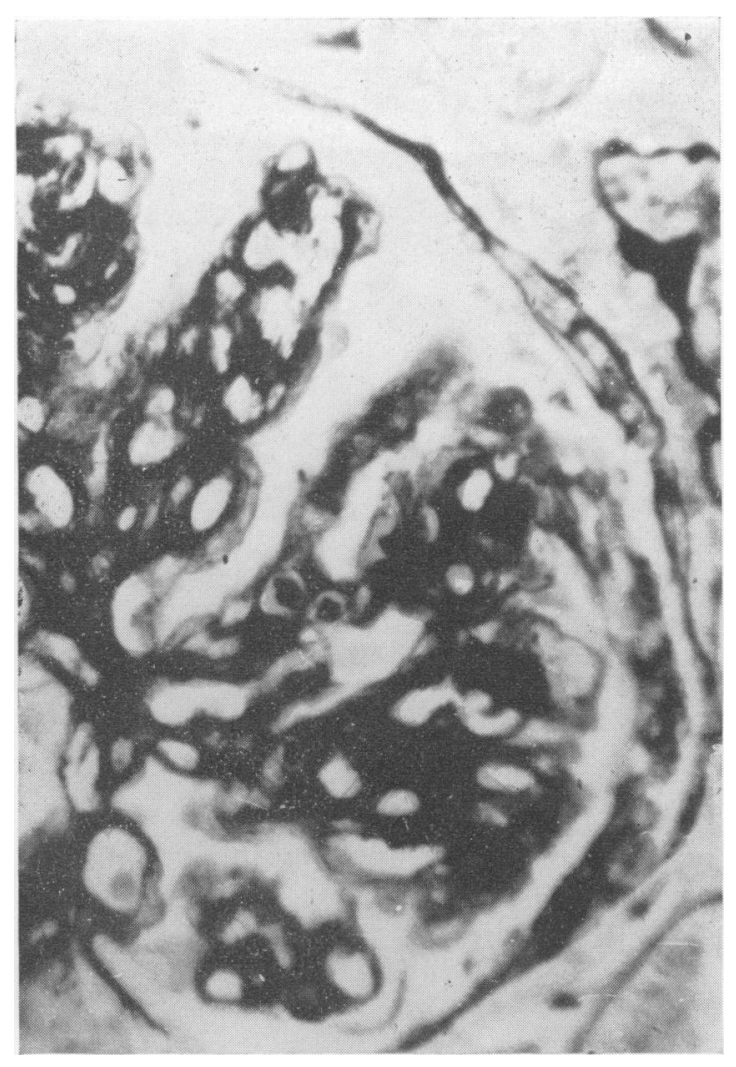

FIG. 8. A portion of a glomerulus showing the 'double staining' of the capillary wall. (Hexamine silver impregnation, $\times 320$ and enlarged.)

serum C3 is always associated with the presence of $\mathrm{C} 3 \mathrm{NeF}$ and vice versa (Peters et al., 1972). Thompson (1972a) has found in the serum of three patients with MPGN and persistent hypocomplementaemia a factor which caused a fall in the total haemolytic activity and electrophoretic conversion of $\mathrm{C} 3$ when mixed and incubated with normal serum. This factor appeared to be chiefly IgG3. Thompson (1972b) then studied twenty-eight patients with MPGN and found that a higher proportion of the serum IgG3 was IgG3 than in normal controls and in patients with other types of renal disease. The IgG3 concentration tended to be higher in those MPGN patients who were hypocomplementaemic at the time of study. Whether IgG3 and $\mathrm{C} 3 \mathrm{NeF}$ are the same substance is as yet not decided. Vallota et al. (1972) noted an inverse correlation between $\mathrm{C} 3$ and $\mathrm{C} 3 \mathrm{NeF}$ in sera from untreated patients with MPGN, but this relationship did not hold in patients being treated with steroids. This finding may parallel Thompson's observations (1972b) that the IgG3 concentration tended to be higher in those MPGN patients who were hypocomplementaemic at the time of study.
No workers as yet have reported measurement of IgG3 and $\mathrm{C} 3 \mathrm{NeF}$ in the same patients.

The complement system may be activated either $\stackrel{\complement}{c}$ by initial binding of $\mathrm{Cla}$ to antibody, the classical $\overrightarrow{\vec{F}}$ pathway, or directly via C3, the alternate pathway $\stackrel{5}{\rightarrow}$ (Gewurg, 1972), and thus spare the early components (C1, C4 and C2). In some patients with MPGN, C1, 흠 $\mathrm{C} 4$ and $\mathrm{C} 2$ have normal concentrations while $\mathrm{C} 3$ is $\frac{\text { के }}{-}$ depressed (Peters et al., 1972). C3b, a breakdown $\stackrel{\Phi}{\varnothing}$ product of $\mathrm{C} 3$, is a necessary component of the alternative pathway, and its involvement constitutes $\vec{\bullet}$ a feedback pathway of complement activation. (Muller-Eberhard \& Gotze, 1973). C3NeF cannot $\vec{\omega}$ brakdown pure C3 (Peters et al., 1972) but requires $\stackrel{\rho}{\circ}$ a co-factor. Williams et al. (1972) have demonstrated 8 that $\mathrm{C} 3 \mathrm{~b}$ is this co-factor, and that it was absent from 3 . the sera of their patients with MPGN. The alterna- $\overrightarrow{0}$ tive pathway of complement activation is, therefore, $i$ important in MPGN, but does not indicate whether of the hypocomplementaemia precedes or follows the nephritis.

Levy, Loirat \& Habib (1973) have demonstrated 은 ultrastructural differences in the glomerular capillary $\vec{\oplus}$ walls of patients with MPGN, correlating with $\mathrm{C} 3 \stackrel{\mathbb{D}}{\mathbb{D}}$ and $\mathrm{C} 4$ serum concentrations. In twelve out of $\frac{\vec{D}}{\mathbb{D}}$ thirty-four patients with dense intramembranous 3 deposits, $\mathbf{C} 3$ concentrations were invariably low and $\mathrm{C} 4$ concentrations were always normal. This sugges $8 \vec{\circ}$ that the alternative pathway was activated during. the mediation of the nephritis. The remaining twents. two patients had subendothelial electron-dense deposits and variable $\mathrm{C} 3$ and $\mathrm{C} 4$ concentrations. This study is of interest because morphological differences in MPGN appear to be related to the alternative pathway mediation. However, this observation is at variance with the fluctuating levels of $\overrightarrow{\vec{O}}$ C3 often found during the course of MPGN (Cameron et al., 1970). Possibly, the ultrastructural morphology of MPGN may vary with the degree of hypocomplementaemia.

\section{Post-streptococcal nephritis}

The transient hypocomplementaemia accompanying this disease is well known. Pickering, Gewurz \& Good (1968) have described a complement inhibiting factor in the serum of some patients with this nephritis. This observation has been extended by Williams et al. (1972) by reporting a serum ' $\mathrm{C} 3 \mathrm{NeF}$ - 을 like' activity in four patients with acute nephritis. This may be important, suggesting that $\mathrm{C} 3 \mathrm{NeF}$ may be a product of an immune reaction per se, and tha $t$ complement in nephritis may have to be considered less directly related to immune inflammation than is currently thought.

High complement in nephritis

Gabriel, Glynn \& Joekes (1972) have reported a 
series of patients with nephritis in which $43 \%$ of the patients had elevated $\mathrm{CH}$ or $\mathrm{C} 3$, or both. The mortality of those patients with an elevated $\mathrm{CH}$ was $62 \%$ and of those with normal $\mathrm{CH} 20 \%$. There were no constant histological findings in those patients with the elevated $\mathrm{CH}$. An elevated $\mathrm{C} 3$ did not have a prognostic significance. A high serum $\mathrm{CH}$ has to be interpreted with care, as $\mathrm{CH}$ is known to be raised in infectious conditions (Osborne, 1937), carcinomatosis (Fischel, 1953) and myocardial infarction (Boltax \& Fischel, 1956). An explanation of the serious prognosis in a nephritic patient with a raised $\mathrm{CH}$ is not available.

\section{Conclusion}

Despite much work attempting to clarify the value of complement measurements in immune renal disease the picture is unclear. As yet little advantage to the clinician has been gained. It is possible that measurement of breakdown products of $\mathrm{C} 3$ and $\mathrm{C} 4$ will be shown to give more information regarding a nephritis than $\mathrm{CH}$ or $\mathrm{C} 3$, as has been shown to be true in rheumatoid arthritis (Versey, Hobbs \& Holt, 1973). As complement is involved secondarily in immune inflammation, and is unrelated to the initiating factors, it may well be that, when possible, study of the causal antigens and the way in which they are processed will prove more fruitful.

\section{References}

AlPer, C.A. \& Rosen, F.S. (1967) Studies of the in vivo behaviour of human $C^{13}$ in normal subjects and patients. Journal of Clinical Investigation, 46, 2021.

Berger, J., YANEVA, H. \& ANTOINE, B. (1969) Etude immunohistochimique des lésions glomérulaires. Journal d'Urologie et de Néphrologie, 76, 269.

Boltax, A.J. \& Fischel, E.E. (1956) Serologic tests for inflammation. American Journal of Medicine, 20, 418.

Cameron, J.S., Glasgow, E.F., OgG, C.S. \& White, R.H.R. (1970) Membrano-proliferative glomerulonephritis and persistent hypocomplementaemia. British Medical Journal, $5,7$.

Cameron, J.S., OgG, C.S., White, R.H.R. \& Glasgow, E.F. (1973) The clinical features and prognosis of patients with normocomplementaemic mesangiocapillary glomerulonephritis. Clinical Nephrology, 1, 8.

Dixon, F.J., VAZquez, J.J., Weigle, W.O. \& Cochrane, C.G. (1958) Pathogenesis of serum sickness. Archives of Pathology, 65, 18 .

Duncan, D.A., Drummond, K.N., Michael, A.F. \& VerNiER, R.L. (1965) Pulmonary haemorrhage and glomerulonephritis. Annals of Internal Medicine, 62, 920.

EARLe, D.P. (1959) In: Proceedings of the 11th Annual Conference on the Nephrotic Syndrome (Ed. by J. P. Metcoff), p. 115. National Disease Foundation, New York.

Fischel, E.E. (1953) Serum complement as an indication of the presence and degree of inflammatory reaction in various diseases. Journal of Clinical Investigation, 32, 568.

Gabriel, R., GlynN, A.A. \& Joekes, A.M. (1972) Raised complement in nephritis: prognostic significance. Lancet, ii, 55 .

Gell, P.G.H., Thomas, C.C. \& Coombes, R.R.A. (1968) In: Clinical Aspects of Immunology, 2nd edn, p. 575. Blackwell Scientific Publications, Oxford.
Gewurg, H. (1972) In: Biological Activities of Complement (Ed. by D. G. Ingram), p. 56. Karger, Basle.

Gottof, S.P., Fellers, F.X., Vawter, G.F., Janeway, C.A. \& ROSEN, F.S. (1965) The beta 1 c globulin in childhood nephrotic syndrome. New England Journal of Medicine, 273, 524.

GuNN, W.C. (1914) The variation in the amount of complement in the blood in some acute infectious disease and its relation to the clinical features. Journal of Pathology and Bacteriology, 19, 155.

HAMmer, D.K. \& DiXon, F.J. (1963) Experimental glomerulonephritis. Immunologic events in the pathogenesis of nephrotic serum nephritis in the rat. Journal of Experimental Medicine, 117, 1019.

Gutman, R.A., Striker, G.E., Gilliland, B.C. \& Cutlerre, P.D. (1972) The immune complex glomerulonephritis of bacterial endocarditis. Medicine, 51, 1.

Herdman, R.C., Pickering, R.J., Michael, A.F., Vernier, R.L., FISH, A.J., Gewurz, H. \& GoOD, R.A. (1970) Chronic glomerulonephritis associated with low serum complement activity (chronic glomerulonephritis hypocomplementemic). Medicine, 49, 207.

Lagrue, G., Brecy, H. \& Hartmen, L. (1969) La complementurie dans les glomerulopathies lumanes. Revue française d'études cliniques et biologiques, 14, 346.

Lam, C.N., MCNeish, A.S. \& Gibson, A.A. (1969) Nephrotic syndrome associated with complement deficiency and Staphylococcus albus bacteraemia. Scottish Medical Journal, 14, 86.

Lambert, P.H. \& Dixon, F.J. (1968) Pathogenesis of the glomerulonephritis of the NZB/W mice. Journal of Experimental Medicine, 127, 507.

LeVY, M., LoIRAT, C. \& HABIB, R. (1973) Idiopathic membranoproliferative glomerulonephritis in children: correlations between light, electron, immunofluorescent microscopic appearances and serum $\mathrm{C} 3$ and $\mathrm{C} 4$ levels. Biomedicine, in press.

Masugi, M. (1933) Uber das Wesen spezifischen Veranderungen den Niere und der Leber durch das Nephrotoxie /bzw das Hepatotxin. Beiträge zur pathologischen Anatomie und zur allgemeinen Pathologie, 91, 82.

MAYER, M.M. (1961) In: Experimental Immunochemistry (Ed. by E. A. Kabat and M. M. Mayer), C. C. Thomas, Springfield, Illinois.

MCGiven, A.R. \& Hicks, J.D. (1967) The development of renal fluorescence in $\mathrm{B} / \mathrm{W}$ mice: immunohistological studies. British Journal of Experimental Pathology, 48, 302.

Muller-Eberhard, H.J. \& Gotze, O. (1973) C3 proactivator convertase and its mode of action. Journal of Experimental Medicine, 135, 1003.

NGU, J.L. \& Soothill, J.F. (1969) Immunoconglutin and complement changes in children with acute nephritis. Clinical and Experimental Immunology, 5, 557.

OsBorne, T.W.B. (1937) Complement Alexin. p. 137. Oxford University Press, London.

Peters, D.K., Martin, A., Weinstein, A., Barratt, T.M., Cameron, J.S., OgG, C.S. \& Latchman, P.J. (1972) Complement studies in membranoproliferative glomerulonephritis. Clinical and Experimental Immunology, 11, 311.

Pickering, R.J., Gewurz, H. \& Good, R.A. (1968) Complement inactivation by serum from patients with acute and hypocomplementemic chronic glomerulonephritis. Journal of Laboratory and Clinical Medicine, 72, 298.

Schur, P.H. \& SANDERSON, J. (1968) Immunologic factors and clinical activity in systemic lupus erythematosis. New England Journal of Medicine, 278, 533.

Soothill, J.F. (1967) Altered complement component $C^{13}$ a (Bic-Bia) in patients with glomerulonephritis. Clinical and Experimental Immunology, 2, 83. 
Spitzer, R.E., Vallota, E.H., Forristal, J., Sudora, E., Sitzel, A., Davis, C.D. \& West, C.D. (1969) Serum C13 lytic system in patients with glomerulonephritis. Science, 164, 436.

ThOMPSON, R.A. (1972a) C3 inactivating factor in the serum of a patient with chronic hypocomplementaemic proliferative glomerulonephritis. Journal of Immunology, 22, 147.

Thompson, R.A. (1972b) IgG3 levels in patients with chronic membranoproliferative glomerulonephritis. British Medical Journal, 1, 282.

Vallota, E. H., Forristal, J., Davis, N.C. \& West, C.D. (1972) The C3 nephritic factor and membranoproliferative nephritis: correlation of serum levels of the nephritic factor with C3 levels, with therapy, and with progression of the disease. Journal of Pediatrics, 80, 947.

Versey, J.M.B., Hobbs, J.R. \& Holt, P.J.L. (1973) Complement metabolism in rheumatoid arthritis. 1. Longitudinal studies. Annals of Rheumatic Diseases, in press.
West, C.D. \& McAdams, A.J. (1970) Serum B ${ }^{1}$ C globulin levels in persistent glomerulonephritis with low serum complement: variability unrelated to clinical course. Nephron, 7, 193.

West, C.D., McAdams, A.J., McConville, J.M., Davis, N.C. \& Holland, N.H. (1965) Hypocomplementemic and normocomplementemic persistent (chronic) glomerulonephritis; clinical and pathological characteristics. Journal of Pediat rics, 67, 1089.

Williams, D.G., Charlesworth, J.A., Lachmann, P.J. \& Peters, D.K. (1973) Role of C3b in the breakdown of C3 in hypocomplementaemic mesangiocapillary glomerulo- $\mathrm{C}$ nephritis. Lancet, i, 447.

Williams, D.G., Kourilsky, O., Morel-Maroger, L. \& Peters, D.K. (1972) C3 breakdown by serum from $\vec{\omega}$ patients with acute post-streptococcal nephritis. Lancet, ii. 360 . 